\title{
LEMBRANÇAS DE ANTÓNIO MACHADO GUERREIRO
}

\author{
Carlos Alberto Medeiros ${ }^{1}$
}

A primeira imagem que guardo de António Machado Guerreiro é a de vê-lo absorvido a trabalhar na secretaria do Centro de Estudos Geográficos, com as feições impenetráveis, como que alheio ao que se passava à sua volta; ocupava aí um lugar resguardado, afastado da porta de acesso e via-se que, além de ser o mais velho, era também o mais categorizado dos escassos funcionários presentes. Foi já nos meus últimos tempos de estudante da licenciatura que tive necessidade de me dirigir a ele, para tratar de algum assunto, cujo conteúdo já não recordo ao certo: mas lembro-me de que cheguei junto da sua secretária e o Senhor Guerreiro - era assim que o chamavam - continuou concentrado no que estava a fazer. Passados uns momentos, levantou a cabeça e pareceu-me que abriu os olhos de espanto por me ver ali; não seria cena inédita, pois os outros funcionários esboçaram mesmo um sorriso. Um tanto intimidado, disse-lhe ao que ia, e a verdade é que o Senhor Guerreiro me acolheu bem, deu seguimento ao que ali me levara e esboçou até um começo de conversa a propósito do meu inconfundível sotaque micaelense (fiquei a saber que tinha passado algum tempo na minha ilha de origem).

António Machado Guerreiro era uma pessoa original; creio que cultivava essa originalidade, mas sem deixar de ser genuíno na sua maneira de ser. Tinha tiradas desconcertantes, fazia observações enigmáticas, não raras vezes carregadas de sentido de humor. Mantinha até ao limite do possível os seus velhos hábitos de trabalho: lembro-me de que fazia à mão as operações aritméticas, nalgum pedaço aproveitável de papel usado, com lápis que ele próprio afiava impecavelmente; depois, com cuidado, confirmava os resultados. Os papéis mais importantes eram guardados, de forma ordenada em função da data, numa gaveta da sua secretária, a única que fechava à chave; alguns de menor dimensão, recibos e determinada quantidade de dinheiro que poderia ser necessária, iam parar a uma pequena caixa de lata, vulgar, mais ou menos dissimulada nessa gaveta. Nunca se deu mal com estes métodos, não via razão para os modificar.

Não se julgue, em função do que fica dito, que Machado Guerreiro era um homem invariavelmente sisudo, taciturno ou, muito menos ainda, intratável e de convívio difícil. Pelo contrário: nas pausas de trabalho, estabelecia facilmente o diálogo, era um excelente contador de histórias, ouvia com atenção o que lhe diziam e fazia os comentários apropriados.

1 Professor Catedrático aposentado da Faculdade de Letras da Universidade de Lisboa. 
Tive ocasião de o conhecer melhor pouco tempo depois de me ter licenciado, a partir da altura em que o professor Orlando Ribeiro me confiou as funções de secretário da Finisterra, que então (1966) começou a publicar-se. Machado Guerreiro tinha a seu cargo a revisão das provas tipográficas e a preparação dos vários textos, incluindo a escolha da colocação das figuras e da sua redução mais conveniente. Mas fazia mais: relia cuidadosamente os textos que iriam ser publicados e sugeria aos seus autores retoques, a correcção de pequenos deslizes e tudo o mais que fosse susceptível de os aperfeiçoar (aliás, tinha o mesmo procedimento em relação à generalidade das outras publicações do Centro de Estudos Geográficos). Ao ajudá-lo, como secretário da Finisterra, aprendi muito com ele: já o tenho dito, já o escrevi, mas quero sublinhar devidamente este facto na presente nota.

A revisão de provas tipográficas não é tarefa fácil: exige uma leitura, não só atenta, mas muito especial, diferente da que se faz habitualmente, de modo a detectar as gralhas frequentemente bem dissimuladas. E, por outro lado, a revisão cuidadosa dos textos põe em evidência palavras arreliadoramente repetidas, vírgulas mal colocadas, trechos com rimas deselegantes, frases demasiado extensas que se podem vantajosamente partir, cacafonias, muitas coisas mais. A colaboração com o Dr. Machado Guerreiro (licenciou-se em Filologia Românica no ano lectivo de 1967/68) foi assim muito importante para mim. Aos poucos fui ganhando prática, passei a dar também a minha opinião ou sugestões diversas e a suscitar discussões amigáveis e enriquecedoras. Às vezes, depois de concluído o trabalho, ficávamos a conversar sobre os mais variados temas e foi assim que tive oportunidade de constatar que o leque de interesses do meu interlocutor era afinal muito amplo.

Quando fiz parte da Comissão Directiva do Centro, à qual acabei por presidir durante 6 anos, confirmei que eram excelentes as qualidades do Dr. Guerreiro como funcionário administrativo. Escrupuloso, honesto, minucioso em tudo o que fazia, competente (procurava informar-se sobre os assuntos com que lidava menos), era uma pessoa na qual se podia confiar sem reservas. Acima de tudo, identificava-se com o organismo onde trabalhava, esforçava-se por contribuir para o seu prestígio, sentia como seus os êxitos conseguidos a nível colectivo e individual, mas também os obstáculos que uma ou outra vez surgiam. Nalguns casos, afigurava-se demasiado lento na maneira de trabalhar, mas essa era uma consequência do seu feitio metódico e a condição que the garantia segurança nos resultados da sua actividade. Não olhava a horários, ficava no Centro o tempo que fosse necessário - e que o período de abertura da Faculdade de Letras permitisse.

O Centro de Estudos Geográficos deve muito a António Machado Guerreiro. Seria impensável não o reconhecer nesta altura. 